\title{
Papel de la proteína C reactiva y la velocidad de sedimentación globular en la predicción de colecistectomía laparoscópica dificultosa: su aplicación en un programa de residencia universitario Role of C-reactive protein and enythrocyte sedimentation rate to predict difficult laproscopic cholecystectomy in a university residency program
}

\author{
Matías H. Loccisano (D), Martín Drago (i), Hernán Todeschini (i), Luis Sarotto (i)
}

Departamento de Cirugía. Hospital de Clínicas José de San Martín, Universidad de Buenos Aires.

Los autores declaran no tener conflictos de interés. Conflicts of interest None declared.

Correspondencia | Correspondence: Matías H. Loccisano e-mail: matiasloccisano@live. com.ar

\section{RESUMEN}

Antecedentes: la colecistectomía laparoscópica es uno de los procedimientos quirúrgicos más frecuentemente realizados. Las diferencias en la anatomía y en el grado de inflamación vesicular suelen causar dificultades técnicas intraoperatorias.

Objetivo: determinar el valor de la proteína $C$ reactiva (PCR) y la velocidad de sedimentación globular (VSG) como predictores de colecistectomía dificultosa y evaluar su aplicación en la planificación prequirúrgica de un programa de residencia universitario.

Material y métodos: se confeccionó un estudio retrospectivo, analítico, en un hospital universitario de tercer nivel. Se incluyeron 104 pacientes adultos operados de colecistectomía laparoscópica por litiasis vesicular sintomática entre enero y julio de 2019. Se categorizó a los pacientes en un grupo de colecistectomías dificultosas y otro de colecistectomías no dificultosas.

Resultados: se obtuvieron diferencias estadísticamente significativas al comparar los valores de VSG y PCR de ambos grupos ( $<<0,001$ ). La sensibilidad de la VSG fue del $100 \%$, la especificidad del $45 \%$, el VPP del $40 \%$ y el VPN de $100 \%$. La sensibilidad de la PCR fue del $87,5 \%$, la especificidad del $86,3 \%$, el VPP del $70 \%$ y el VPN de 95\%. Ambos parámetros se vieron elevados en 14 de 16 colecistectomías dificultosas y en 2 de 44 colecistectomías no dificultosas. La sensibilidad para ambos parámetros elevados fue del $87,5 \%$, la especificidad del $95 \%$, el VPP del $87,5 \%$ y el VPN de $95 \%$.

Conclusión: la VSG y la PCR han demostrado ser un método fiable en la predicción de colecistectomías dificultosas por litiasis vesicular sintomática. Esto podría ser aplicado en la programación de cirugías dentro de un programa de residencia universitario.

Palabras clave: PCR, VSG, colecistectomía dificultosa, escala de Parkland.

\section{ABSTRACT}

Background: laparoscopic cholecystectomy is one of the most common procedures performed in general surgery. The anatomical differences of the gallbladder and the presence of factors related to inflammation can cause technical issues during surgery.

Objective: the aim of the present study was to determine the value of C-reactive protein (CRP) and erythrocyte sedimentation rate (ESR) as predictors of difficult cholecystectomy and to evaluate their application during presurgical planning within a university residency program.

Material and methods: we conducted a retrospective and analytical study in a tertiary university hospital. A total of 104 adult patients undergoing laparoscopic cholecystectomy due to symptomatic cholelithiasis between January and July 2019 were included. The patients were categorized into two groups: difficult cholecystectomy and non-difficult cholecystectomy.

Results: there were statistically significant differences in ESR and CRP values between both groups ( $p$ $<0.001$ ). Sensitivity of ESR was $100 \%$, specificity was $45 \%$, with a PPV of $40 \%$ and NPV of $100 \%$. Sensitivity of CRP was $87.5 \%$, specificity was $86.3 \%$, with a PPV of $70 \%$ and NPV of $95 \%$. Both parameters were elevated in 14 of 16 difficult cholecystectomies and in 2 of 44 non-difficult cholecystectomies. Sensitivity of CRP was $87.5 \%$, specificity was $86.3 \%$, with a PPV of $70 \%$ and NPV of $95 \%$.

Conclusion: measuring ESR and CRP has proved to be a reliable method to predict difficult cholecystectomies due to symptomatic cholelithiasis. This could be applied for surgical planning within a university residency program.

Keywords: CRP, ESR, difficult cholecystectomy, Parkland score.
Recibido | Received 29-10-19 Aceptado | Accepted 31-01-20
ID ORCID: Matías H. Loccisano, 0000-0002-3870-2249; Martín Drago, 0000-0002-1563-6656; Hernán Todeschini, 0000-0001-5100-3760; Luis Sarotto, 0000-0002-7480-7144 
Introducción

La colecistectomía laparoscópica es uno de los procedimientos quirúrgicos más frecuentemente realizados en cirugía general ${ }^{1}$. Las diferencias en la anatomía y en el grado de inflamación vesicular suelen causar dificultades técnicas intraoperatorias ${ }^{2}$ y requieren eventualmente conversión ${ }^{3}$.

Existen diferentes escalas para objetivar el grado de dificultad de una colecistectomía ${ }^{4,5}$. También es sabido que ciertos reactantes de fase aguda como la PCR y la VSG elevan su concentración plasmática al menos un $25 \%$ en respuesta al estímulo de ciertas citoquinas proinflamatorias ${ }^{6}$.

Sin embargo, no existe relación entre la elevación de dichos valores plasmáticos y el grado de dificultad de una colecistectomía laparoscópica por litiasis vesicular sintomática.

Por otra parte, resulta importante establecer pruebas analíticas accesibles y de bajo costo que determinen en forma preoperatoria el grado de dificultad que tendrá una colecistectomía, a fin de programar un equipo quirúrgico idóneo?.

El objetivo del presente trabajo fue determinar el valor de la PCR y la VSG como predictores de colecistectomía dificultosa y evaluar su aplicación en la planificación prequirúrgica de un programa de residencia universitario.

\section{Material y métodos}

Se confeccionó un estudio retrospectivo, analítico, en un hospital universitario de tercer nivel.

Se registraron los valores de IMC (índice de masa corporal), PCR (proteína C reactiva) y VSG (velocidad de sedimentación globular) preoperatorios de 104 pacientes sometidos a colecistectomía laparoscópica, en el período comprendido entre enero y julio de 2019. Todas las cirugías fueron realizadas por médicos residentes de segundo o tercer año, supervisados por cirujanos especialistas en vía biliar.

Se incluyeron pacientes adultos operados de colecistectomía laparoscópica por litiasis vesicular sintomática, es decir, aquellos portadores de colelitiasis con dolor cólico. Se excluyeron pacientes con enfermedades reumatológicas o procesos infecciosos agudos concomitantes $^{4}$ y aquellos pacientes con diagnóstico preoperatorio de cáncer de vesícula ${ }^{1}$, síndrome de Mirizzi $^{3}$, colecistitis aguda ${ }^{22}$, coledocolitiasis ${ }^{8}$ y pancreatitis aguda ${ }^{6}$.

El grado de dificultad de la colecistectomía fue categorizado de acuerdo con la escala de Parkland (Tabla 1). Se categorizó a los pacientes en dos grupos: uno de colecistectomías dificultosas, que incluyó los grados 3, 4 y 5 de la escala, y otro de colecistectomías no dificultosas, que incluyó aquellas que presentaron grados 1 y 2 de Parkland.

\section{- TABLA 1}

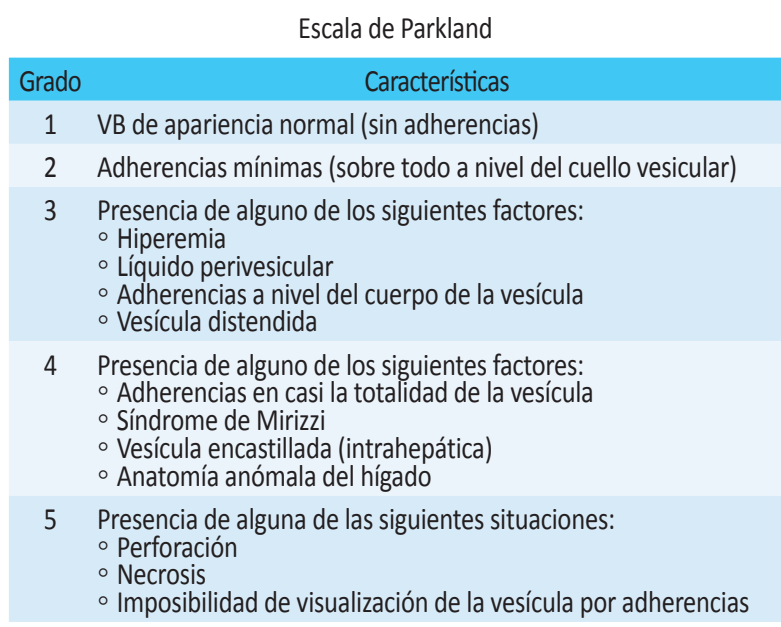

Tomado de Madni, $2017^{4}$

El análisis estadístico se llevó a cabo correlacionando los valores de PCR y VSG preoperatorios (valores de corte: $0,5 \mathrm{mg} / \mathrm{dL}$ para la PCR y $10 \mathrm{~mm} / \mathrm{h}$ para la VSG) en ambos grupos de pacientes. Se aplicó la prueba exacta de Fisher para establecer diferencias estadísticamente significativas entre el grupo de colecistectomía dificultosa y el de colecistectomía no dificultosa. El software utilizado fue Microsoft Excel $2013^{\circledR}$.

Se tomaron los recaudos éticos según las recomendaciones de Helsinki y Tokio y sus modificaciones posteriores. Los datos clínicos fueron protegidos de modo que no se pueda identificar a quién pertenecen y no sean accesibles a personas no comprometidas con el secreto profesional. Todos los pacientes firmaron el consentimiento informado aprobado por el Comité de Ética de la Institución.

\section{Resultados}

Sesenta ( $n=60$ ) pacientes fueron operados por litiasis vesicular sintomática durante el mencionado período y constituyen la población del presente estudio. El promedio de edad fue de 41,2 años (DS 15,9; rango 21 a 76 años); 16 fueron hombres y 44 mujeres.

La población se distribuyó de acuerdo con la escala de Parkland de la siguiente manera: 4 pacientes fueron grado 1 (7\%), 40 pacientes grado 2 (67\%), 12 pacientes grado $3(20 \%), 2$ pacientes grado $4(3 \%)$ y 2 pacientes grado 5 (3\%) (Tabla 2).

El abordaje en todos los casos fue laparoscópico; en uno de ellos se hizo conversión por advertirse una fístula colecistocoledociana en forma intraoperatoria $(1,67 \%)$.

El grupo de colecistectomías dificultosas (Parkland 3, 4 o 5) tuvo un total de 16 pacientes (27\%), de los cuales 12 fueron mujeres. El promedio de edad fue de 42,1 años y la media de IMC fue $26 \mathrm{~kg} / \mathrm{m}^{2}$. La 
VSG y la PCR se vieron incrementadas en $16(100 \%)$ y en $14(87,5 \%)$ pacientes, respectivamente. Los valores de VSG y PCR se mantuvieron dentro del rango de normalidad en $0(0 \%)$ y $2(12 \%)$ pacientes, respectivamente.

El grupo de colecistectomías no dificultosas (Parkland $1 \circ 2$ ) tuvo un total de 44 pacientes (73\%), de los cuales 32 fueron mujeres. El promedio de edad fue de 43,8 años y la media de IMC fue $21 \mathrm{~kg} / \mathrm{m}^{2}$. La VSG y la PCR se vieron incrementadas en 24 (54\%) y en 6 (14\%) pacientes, respectivamente. Los valores de VSG y PCR se mantuvieron dentro del rango de normalidad en $20(45 \%)$ y $38(86 \%)$ pacientes, respectivamente.

No se hallaron diferencias estadísticamente significativas en cuanto a edad, sexo e IMC entre ambos grupos. El IMC en promedio fue mayor en el grupo de colecistectomías dificultosas (Tabla 3).

La prueba exacta de Fisher demostró diferencias estadísticamente significativas al comparar los valores de VSG y PCR de ambos grupos $(p<0,001)$ (Tabla 4).

La sensibilidad de la VSG fue del $100 \%$, la especificidad del $45 \%$, el VPP del $40 \%$ y el VPN de $100 \%$. La sensibilidad de la PCR fue del $87,5 \%$, la especificidad del $86,3 \%$, el VPP del $70 \%$ y el VPN de $95 \%$. Ambos parámetros se vieron elevados en 14 de 16 colecistectomías dificultosas y en 2 de 44 colecistectomías no dificultosas. La sensibilidad para ambos parámetros elevados fue del $87,5 \%$, la especificidad del $95 \%$, el valor predictivo positivo (VPP) del $87,5 \%$ y el valor predictivo negativo (VPN) de 95\% (Tabla 5).

\section{- TABLA 2}

Distribución de la población de acuerdo con la escala de Parkland

\begin{tabular}{|c|c|c|c|c|}
\hline Grado & $\begin{array}{c}\text { Número de } \\
\text { pacientes }(n=60)\end{array}$ & $\%$ & Tipo de colecistectomía & $\%$ \\
\hline 1 & 4 & 7 & \multirow{2}{*}{ No dificultosa $(n=44)$} & \multirow{2}{*}{73} \\
\hline 2 & 40 & 67 & & \\
\hline 3 & 12 & 20 & \multirow{3}{*}{ Dificultosa $(n=16)$} & \multirow{3}{*}{27} \\
\hline 4 & 2 & 3 & & \\
\hline 5 & 2 & 3 & & \\
\hline
\end{tabular}

\section{- TABLA 3}

Distribución de la población según edad, sexo e IMC

\begin{tabular}{lccc} 
& $\begin{array}{c}\text { Dificultosa } \\
\text { (Parkland 3-4-5) }\end{array}$ & $\begin{array}{c}\text { No dificultosa } \\
\text { (Pakland 1-2) }\end{array}$ & $\mathrm{p}^{*}$ \\
$\begin{array}{l}\text { Edad } \\
\text { (Promedio) }\end{array}$ & 42,1 & 43,8 & 0,09 \\
$\begin{array}{l}\text { Sexo } \\
\text { Femenino }\end{array}$ & 12 & 32 & 0,24 \\
$\begin{array}{l}\text { Imc } \\
\text { (Promedio) }\end{array}$ & 26,2 & 21,3 & 0,41 \\
\hline
\end{tabular}

*Según prueba exacta de Fisher.

\section{TABLA 4}

Resultados de las pruebas analíticas de acuerdo con la dificultad de la colecistectomía y su correlación estadística

$\begin{array}{lcccc} & \begin{array}{c}\text { Dificultosa } \\ \text { (Parkland 3-4-5) }\end{array} & \begin{array}{c}\text { No dificultosa } \\ \text { (Pakland 1-2) }\end{array} & n & \text { p* } \\ \text { PCR elevada } & 14 & 6 & 20 & <0,001 \\ \text { PCR normal } & 2 & 38 & 40 & <0,001 \\ \text { n } & 16 & 44 & 60 & \\ \text { VSG elevada } & 16 & 24 & 40 & <0,001 \\ \text { VSG normal } & 0 & 20 & 20 & <0,001 \\ \text { n } & 16 & 44 & 60 & \\ \text { VSG + PCR elevada } & 14 & 2 & 16 & <0,001 \\ \text { VSG + PCR normal } & 2 & 42 & 44 & <0,001 \\ \text { n } & 16 & 44 & 60 & \end{array}$

*Según prueba exacta de Fisher.

\section{- TABLA 5}

Sensibilidad, especificidad, VPP y VPN de cada una de las pruebas

\begin{tabular}{|ccccc|}
\hline & Sensibilidad & Especificidad & VPP & VPN \\
\hline VSG & $100 \%$ & $45 \%$ & $40 \%$ & $100 \%$ \\
\hline PCR & $87,5 \%$ & $86,3 \%$ & $70 \%$ & $95 \%$ \\
\hline VSG + PCR & $87,5 \%$ & $95 \%$ & $87,5 \%$ & $95 \%$ \\
\hline
\end{tabular}

VPP: valor predictivo positivo; VPN: valor predictivo negativo.

\section{Discusión}

La VSG ha demostrado ser una prueba altamente sensible en la predicción de colecistectomía dificultosa, pero con escasa especificidad. Este resultado debe ser confirmado con una prueba altamente específica como lo demostró ser la PCR, ya que al obtener ambos resultados positivos la especificidad asciende considerablemente ( $95 \%$ en nuestra serie), permitiendo predecir preoperatoriamente una colecistectomía dificultosa. Por otra parte, una VSG negativa descarta completamente la posibilidad de encontrarse frente a una colecistectomía dificultosa, debido a su altísimo VPN.

Distintos reactantes de fase aguda han sido valorados como predictores de colecistectomía dificultosa. La procalcitonina ha demostrado ser más sensible y específica que la VSG y/o PCR para este $\mathrm{fin}^{8}$, aunque en nuestro medio su costo es mucho mayor y su disponibilidad es prácticamente nula. Por otra parte, se ha demostrado que un incremento en la PCR se asocia tanto a un incremento en la tasa de conversión ${ }^{9}$ como a gangrena vesicula $r^{10}$ y piocolecisto en colecistitis agudas ${ }^{11}$. Sin embargo, no se han publicado resultados respecto de litiasis vesiculares sintomáticas.

La tomografía computarizada con contraste endovenoso cumple un papel en la predicción de dificultad. Se ha demostrado que un retraso en el lavado de contraste en fase arterial está directamente relacio- 
nado con un incremento del tiempo operatorio, mayor sangrado durante la cirugía, lesión quirúrgica de la vía biliar y conversión ${ }^{12}$.

Una colecistectomía dificultosa puede ser identificada y resuelta fácilmente por un cirujano experimentado, ya que ha desarrollado y posee las herramientas técnicas para hacerlo². En cambio, un cirujano en formación o un médico residente de cirugía debe identificar, en primera instancia, los pasos de una colecistectomía reglada para luego ir desarrollando sus habilidades quirúrgicas en orden de dificultad creciente ${ }^{13}$.

Es sabido que las colecistectomías dificultosas presentan mayor número de complicaciones y mayor grado de severidad en la escala de Clavien-Dindo que las colecistectomías simples ${ }^{14}$. Además, la técnica quirúrgica entre un escenario y otro puede cambiar, requiriendo realizar colecistectomías subtotales o parciales (Zabala-Bengolea, Pribram, Doyene) ${ }^{15,16}$. Incluso la colecistectomía de urgencia es un factor de riesgo independiente para conversión ${ }^{17}$. Es por ello que identificar en forma preoperatoria el grado de dificultad de una colecistectomía, mediante un método de valoración objetiva puede resultar de gran ayuda a la hora de programar una cirugía dentro de un programa de residencia universitario.

Teniendo esto en cuenta y de acuerdo con lo expuesto previamente, es factible proponer el un algoritmo de manejo (Fig. 1). De manera tal que se debería iniciar con la medición de VSG: si resulta negativa, se considera que la colecistectomía no será dificultosa. De ser positiva, es menester confirmar este resultado con la medición de PCR y, si esta resulta positiva, la colecistectomía será dificultosa. En caso contrario, descarta esta posibilidad.

Este algoritmo podría constituir una herramienta de utilidad a la hora de planificar la participación

\section{口 FIGURA 1}

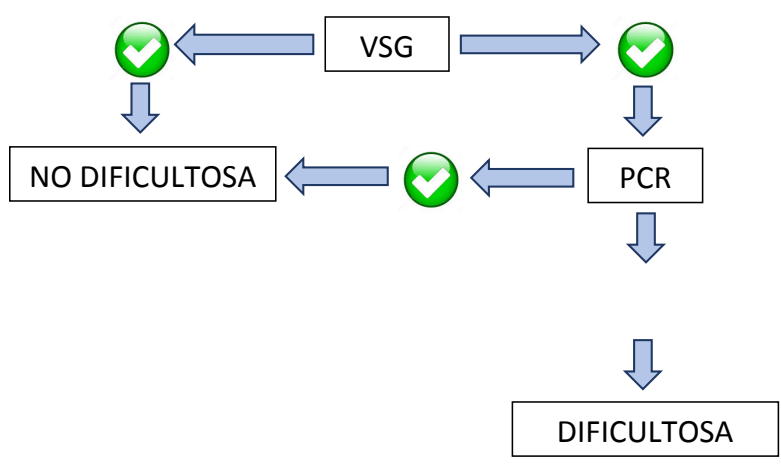

Algoritmo de manejo preoperatorio

activa de los médicos residentes de cirugía. Diríamos a priori que los pacientes con baja sospecha de dificultad formarían la parte inicial del proceso de adquisición de habilidades laparoscópicas por parte de los médicos residentes de cirugía, mientras que aquellos con alta sospecha de dificultad quedarían reservados para médicos residentes con mayor cantidad de competencias quirúrgicas adquiridas, completando así la compleja curva de aprendizaje en laparoscopia.

En conclusión, la VSG y la PCR han demostrado ser un método fiable en la predicción de colecistectomías dificultosas por litiasis vesicular sintomática. Esto podría ser aplicado en la programación de cirugías dentro de un programa de residencia universitario, teniendo en cuenta el desarrollo de habilidades quirúrgicas en orden de complejidad creciente. Sin embargo, deberían confirmarse estos hallazgos mediante el análisis de una población con mayor número de pacientes operados.

\section{- ENGLISH VERSION}

\section{Introduction}

Laparoscopic cholecystectomy is one of the most common procedures performed in general surgery ${ }^{1}$. The anatomical differences of the gallbladder and the presence of factors related to inflammation can cause technical issues during surgery ${ }^{2}$ and may lead to conversion ${ }^{3}$.

There are different scoring methods to predict difficulty for cholecystectomy ${ }^{4,5}$. It is also known that certain acute-phase proteins such as C-reactive protein (CRP) and erythrocyte sedimentation rate (ESR) raise by at least $25 \%$ in response to the release of certain proinflammatory cytokines ${ }^{6}$.

However, there is no relationship between their elevation and the degree of difficulty of a laparoscopic cholecystectomy for symptomatic cholelithiasis.

Furthermore, it is important to establish accessible and low-cost laboratory tests to predict the difficulty level of cholecystectomy before surgery in order to select a suitable surgical team ${ }^{7}$.

The aim of the present study was to determine the value of CRP and ESR as predictors of difficult cholecystectomy and to evaluate their application during presurgical planning within a university residency program.

\section{Material and methods}

We conducted a retrospective and analytical study in a tertiary university hospital.

Preoperative body mass index (BMI), CRP and ESR of 104 patients undergoing laparoscopic cholecystectomy between January and July 2019 
were recorded. All the surgeries were performed by second- or third-year residents, supervised by surgeons specialized in biliary surgery.

Patients undergoing laparoscopic cholecystectomy due to symptomatic cholelithiasis (with biliary colic) were included. Those patients with rheumatological diseases or concomitant acute infections ${ }^{4}$, preoperative diagnosis of gallbladder cancer $^{1}$, Mirizzi syndrome ${ }^{3}$, acute cholecystitis ${ }^{22}$, choledocholithiasis $^{8}$ and acute pancreatitis6 were excluded from the study.

Cholecystitis severity grade was categorized using the Parkland grading scale (Table 1). The patients were categorized into two groups: difficult cholecystectomy, which included grades 3, 4 and 5 of the Parkland scale, and non-difficult cholecystectomy, which included grades 1 and 2 .

The statistical analysis was performed by correlating the preoperative values of CPR and ESR (cutoff values: $0.5 \mathrm{mg} / \mathrm{dL}$ for CRP and $10 \mathrm{~mm} / \mathrm{h}$ for ESR) in both groups of patients. Fisher's exact test was used to establish the statistically significant differences between both groups. All calculations were performed using Microsoft Excel 2013 spreadsheet.

The study was conducted following the ethical principles of the Declaration of Helsinki and revised in Tokyo. The clinical data were protected so as not to identify to whom they belong and not to be accessible to persons not bound by professional secrecy. All the patients signed an informed consent form approved by the Committee on Ethics of the institution.

\section{Results}

A total of 60 patients underwent laparoscopic cholecystectomy due to symptomatic cholelithiasis during the mentioned period and constitute the

\begin{tabular}{ll} 
n TABLE 1 \\
Grade & \multicolumn{1}{c}{ Charkacteristics } \\
1 & Normal appearing gallbladder (no adhesions present) \\
2 & Minor adhesions at neck \\
& $\begin{array}{l}\text { Presence of any of the following: } \\
\text { Hyperemia } \\
\text { Pericholecystic fluid } \\
\text { Adhesions to the body } \\
\text { Distended gallbladder }\end{array}$ \\
& $\begin{array}{l}\text { Presence of any of the following: } \\
\text { Adhesions obscuring majority of gallbladder } \\
\text { Mirizzi syndrome } \\
\text { Intrahepatic gallbladder } \\
\text { Abnormal liver anatomy }\end{array}$ \\
4 & $\begin{array}{l}\text { Presence of any of the following: } \\
\text { Perforation } \\
\text { Necrosis } \\
\text { Inability to visualize the gallbladder due to adhesions }\end{array}$
\end{tabular}

From Madni, $2017^{4}$ population of the present study. Mean age was 41.2 years (SD: 15.9; range: 21-76); 16 were men and 44 were women.

The population was distributed according to the Parkland grading scale as follows: grade 1,4 patients (7\%); grade 2,40 patients $(67 \%)$; grade 3,12 patients (20\%); grade 4, 2 patients (3\%); and grade 5, 2 patients (3\%) (Table 2).

All the procedures were performed through laparoscopy; in one case, conversion was necessary due to the presence of a cholecystocholedochal fistula found at surgery $(1.67 \%)$.

Sixteen patients $(27 \%, 12$ women) presented difficult cholecystectomies (Parkland categories 3, 4 and 5). Mean age was 42.1 years and mean BMI was $26 \mathrm{~kg} / \mathrm{m} 2$. ERS and CRP were increased in $16(100 \%)$ and $14(87.5 \%)$ patients, respectively, and remained within normal values in $0(0 \%)$ and $2(12 \%)$ patients, respectively.

Forty-four patients (73\%, 32 women) presented non-difficult cholecystectomies (Parkland categories 1 and 2). Mean age was 43.8 years and mean BMI was $21 \mathrm{~kg} / \mathrm{m} 2$. ESR and CRP were increased in 24 (54\%) and $6(14 \%)$ patients, respectively. and remained within normal values in $20(45 \%)$ and 38 (86\%) patients, respectively.

There were no significant differences in age, sex and BMI between both groups. Mean BMI was greater in the difficult cholecystectomy group (Table 3 ).

Fisher's exact test demonstrated statistically significant differences in ESR and CRP values $(p<0.001)$ between both groups (Table 4).

Sensitivity of ESR was $100 \%$, specificity was $45 \%$, with a PPV of $40 \%$ and NPV of $100 \%$. Sensitivity of CRP was $87.5 \%$, specificity was $86.3 \%$, with a PPV of $70 \%$ and NPV of $95 \%$. Both parameters were elevated in 14 of 16 difficult cholecystectomies and in 2 of 44

\section{- TABLE 2}

Distribution of the population by Parkland grading scale

\begin{tabular}{ccccc}
\hline Grade & $\begin{array}{c}\text { Number of } \\
\text { patients }(n=60)\end{array}$ & $\%$ & Type of cholecystectomy & $\%$ \\
\hline 1 & 4 & $7 \%$ & Non-difficult $(n=44)$ & $73 \%$ \\
2 & 40 & $67 \%$ & & \\
3 & 12 & $20 \%$ & Difficult $(n=16)$ & $27 \%$ \\
4 & 2 & $3 \%$ & & \\
\hline 5 & 2 & $3 \%$ & & \\
\hline
\end{tabular}

\section{- TABLE 3}

Distribution of the population by age, sex and BMI

\begin{tabular}{|c|c|c|c|}
\hline & $\begin{array}{c}\text { Difficult } \\
\text { (Parkland grade 3-4-5) }\end{array}$ & $\begin{array}{l}\text { Difficult } \\
\text { (Parkland grade 1-2) }\end{array}$ & $p^{*}$ \\
\hline $\begin{array}{c}\text { Age } \\
\text { (Average) }\end{array}$ & 42.1 & 43.8 & 0.09 \\
\hline $\begin{array}{l}\text { Sex } \\
\text { Female }\end{array}$ & 12 & 32 & 0.24 \\
\hline $\begin{array}{c}\text { Bmi } \\
\text { (Average) }\end{array}$ & 26.2 & 21.3 & 0.41 \\
\hline
\end{tabular}


non-difficult cholecystectomies. For both elevated parameters, sensitivity was $87.5 \%$ and specificity was 95\%, with a PPV of $87.5 \%$ and a NPV of $95 \%$ (Table 5).

\section{Discussion}

ERS has proved to be highly sensitive for predicting difficult cholecystectomy, but its specificity is low. This result must be confirmed with a highly specific test as CRP, as specificity rises considerably when both results are positive (95\% in our series), allowing preoperative prediction of difficult cholecystectomy. On the other hand, a negative ESR undoubtedly rules out the possibility of facing a difficult cholecystectomy due to its high NPV.

Different acute-phase proteins have been evaluated as predictors of difficult cholecystectomy. Procalcitonin has demonstrated to be more sensitive and specific than ESR and CRP for this purpose ${ }^{8}$, although in our environment it is more expensive and almost unavailable. In addition, elevated CRP is associated with an increase in the rate of conversion ${ }^{9}$, gangrenous cholecystitis ${ }^{10}$ and gallbladder empyema in acute cholecystitis ${ }^{11}$. However, there are no publications about symptomatic cholelithiasis.

Contrast-enhanced computed tomography scan plays a role in predicting difficult cholecystectomy. It has been demonstrated that attenuation during the arterial phase is directly associated with longer operative time, greater bleeding during surgery, bile duct injury and conversion ${ }^{12}$.

A difficult cholecystectomy can be easily identified and resolved by a well-trained surgeon

\begin{tabular}{lccccc}
\hline TABLE 4 \\
\hline \multicolumn{5}{c}{ Results of blood tests by difficult cholecystectomy and its statistical } \\
correlation
\end{tabular}

\section{TABLE 5}

Sensitivity, specificity, PPV and NPV of each test

$\begin{array}{lcccc} & \text { Sensitivity } & \text { Specificity } & \text { PPV } & \text { NPV } \\ \text { ESR } & 100 \% & 45 \% & 40 \% & 100 \% \\ \text { CRP } & 87.5 \% & 86.3 \% & 70 \% & 95 \% \\ \text { ERS + CRP } & 87.5 \% & 95 \% & 87.5 \% & 95 \%\end{array}$

PPV: positive predictive value; NPV: negative predictive value. with experience and technical skills ${ }^{2}$. Instead, surgical trainees or residents in surgery should firstly identify the steps of a standardized method for cholecystectomy and then develop their surgical skills ${ }^{13}$.

Difficult cholecystectomies are associated with greater number of complications, which are more severe according to the Clavien-Dindo classification than simple cholecystectomies ${ }^{14}$. In addition, the surgical technique between one and another scenario may change, requiring subtotal or partial cholecystectomies (Zabala-Bengolea, Pribram, Doyene) ${ }^{15,16}$. Even more, emergency surgery is an independent risk factor for conversion17. Thus, the possibility of identifying a difficult cholecystectomy in the preoperative period by means of an objective assessment method can be very helpful for surgical planning within a university residency program.

Bearing this in mind, and in line with what has been previously mentioned, it is feasible to propose a management algorithm (Fig. 1). Firstly, measure ESR. If negative, cholecystectomy will not be difficult. If positive, measure CRP. If positive, cholecystectomy will be difficult. If negative, cholecystectomy will not be difficult.

This algorithm could constitute a useful tool when planning the active participation of residents in surgery. We would say that patients with low probability of difficult cholecystectomy would constitute the initial stage for the acquisition of laparoscopic skills during residency training, while those with a high probability of difficult cholecystectomy could be operated on by residents with a higher level of surgical skills, thus completing the complex learning curve in laparoscopy.

In conclusion, measuring ESR and CRP has proved to be a reliable method to predict difficult cholecystectomies due to symptomatic cholelithiasis. This could be applied for surgical planning within a university residency program, considering the acquisition of more complex surgical skills. These findings should be confirmed by analyzing larger populations of patients.

\section{- FIGURE 1}

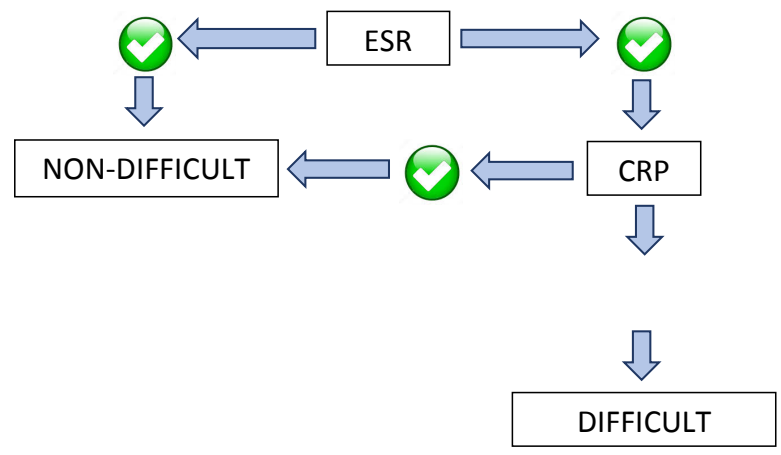

Preoperative management algorithm 
1. Tf $Y$, Guo L, Wang Q. Evaluation of Preoperative Risk Factor for Converting Laparoscopic to Open Cholecystectomy: Hepatogastroenterology. 2014;61(132):2014.

2. Wakabayashi G, Iwashita Y, Hibi T, Takada T, Strasberg SM, Asbun HJ. Tokyo Guidelines 2018 : surgical management of acute cholecystitis: safe steps in laparoscopic cholecystectomy for acute cholecystitis (with videos). J Hepatobiliary Pancreat Sci. 2018;2018(25):73-86. doi:10.1002/jhbp.517.

3. Panni RZ, Strasberg SM. Preoperative predictors of conversion as indicators of local in fl ammation in acute cholecystitis: strategies for future studies to develop quantitative predictors. J Hepatobiliary Pancreat Sci. 2018;2018(25):101-108. doi:10.1002/ jhbp.493.

4. Madni TD, Leshikar DE, Minshall CT, et al. The Parkland grading scale for cholecystitis. Am J Surg. 2017. doi:10.1016/j.amjsurg.2017.05.017.

5. Soltes $M$, Radoňak J. A risk score to predict the difficulty of elective laparoscopic cholecystectomy. Videosurgery miniinv. 2014;9(4):608-612. doi:10.5114/wiitm.2014.47642.

6. Ananian P, Hardwigsen J, Bernard D, Le Treut YP. Serum acute-phase protein level as indicator for liver failure after liver resection. Hepatogastroenterology. 2005 May-Jun;52(63):857-61.

7. Atta HM, Mohamed AA, Sewefy AM, Mohammed MM, Atiya AM. Difficult Laparoscopic Cholecystectomy and Trainees: Predictors and Results in an Academic Teaching Hospital. Gastroenterol Res Pract. 2017;2017:1-5. doi:10.1155/2017/6467814.

8. Wu T, Luo M, Guo Y, Bi J, Guo Y, Bao S. Role of procalcitonin as a predictor in difficult laparoscopic cholecystectomy for acute cholecystitis case : A retrospective study based on the TG18 criteria. Sci Rep. 2019;(July):1-7. doi:10.1038/s41598-019-47501-0.

9. Patijn GA. Laparoscopic Cholecystectomy in Acute Cholecystitis :
C-Reactive Protein Level Combined With Age Predicts Conversion. Surg Laparosc Endosc Percutan Tech. 2013;23(2):163-6.

10. Gomes CA, Junior CS, Saverio S Di, et al. Gangrenous cholecystitis in male patients: A study of prevalence and predictive risk factors. Ann Hepatobiliary Pancreat Surg. 2019;23:34-40.

11. Juvonen $T$, Kiviniemi $H$, Niemelä OKM. Diagnostic accuracy of ultrasonography and $\mathrm{C}$ reactive protein concentration in acute cholecystitis : a prospective clinical study. Eur J Surg. 1992;158(67):365-9.

12. Maehira $\mathrm{H}$, Kawasaki $\mathrm{M}$, Itoh $\mathrm{A}$, et al. Prediction of difficult laparoscopic cholecystectomy for acute cholecystitis. J Surg Res. 2017;2017: 1-17. doi:10.1016/j.jss.2017.05.008.

13. Cornelia Lindlohr R, Lefering S, Saad MM, Heiss CPK. Training or non-surgical factors - what determines a good surgical performance? A randomised controlled trial. Langenbecks Arch Surg. 2017;2017:1-9. doi:10.1007/s00423-017-1567-8.

14. Domenico G, Angela T, Sean B, Abdul K, Khan Q. Day-case laparoscopic cholecystectomy : analysis of the factors allowing early discharge. Updates Surg. 2017. doi:10.1007/s13304-017-0433-

15. Elshaer M, Gravante G, Thomas K, Sorge R, Al-Hamali S, Hamdi Ebdewi M. Subtotal Cholecystectomy for "Difficult Gallbladders" Systematic Review and Meta-analysis. JAMA Surg. 2015;150(2):159 68. doi:10.1001/jamasurg.2014.1219.

16. Mok KWJ, Reddy R, Wood F, et al. Is C-reactive protein a useful adjunct in selecting patients for emergency cholecystectomy by predicting severe/gangrenous. Int J Surg. 2014;(May):1-5. doi:10.1016/j.ijsu.2014.05.040.

17. Chávez K V, Márquez $H$, Itzé $G$, Juan A. Prognostic risk factors for conversion in laparoscopic cholecystectomy. Updates Surg. 2017. doi:10.1007/s13304-017-0494-0. 